\title{
Fair Trial Rights in ICCPR
}

\author{
Jixi Zhang \\ Southwest University of Political Science and Law, Chongqing, 401120, China \\ Tel: 86-23-6725-8471Ｅ-mail: jixizhang@gmail.com
}

\begin{abstract}
Articles 14 and 15 in ICCPR provide fair trial rights. The 16 concrete guarantees of fair trial rights are usually classified into three parts: basic rules, minimum guarantees and other provisions. A proceeding complying by those concrete guarantees can not necessarily accord with the requirement of fair trial rights, because article 14, paragraph 1 provides a special kind of right - the general right to a fair trial. Unlike the concrete guarantees, the general right to a fair trial requires to evaluate the proceedings as a whole. In the process of interpreting ICCPR, the Human Rights Committee has added more and more concrete guarantees to fair trial rights via the general right to a fair trial.
\end{abstract}

Keywords: Fair trial rights, ICCPR, The general right to a fair trial

Fair trial rights, also referred to as the right to a fair trial, is one of the most important fundamental human rights. Since articles 10 and 11 of Universal Declaration of Human Rights acknowledged fair trial rights in 1948, they have been provided by many international human rights documents, such as International Covenant on Civil and Political Rights (simply referred to as ICCPR in the followings), Convention for Protection of Human Rights and Fundamental Freedoms, American Convention on Human Rights, African Charter on Human and Peoples' Rights, etc.. Among these international human rights documents, articles 14 and 15 in ICCPR are the most detailed provisions on fair trial rights.

Article 14 is of a particularly complex nature, combining various guarantees. The first sentence of paragraph 1 sets out a general guarantee of equality before courts and tribunals that applies regardless of the nature of proceedings before such bodies. The second sentence of the same paragraph entitles individuals to a fair and public hearing by a competent, independent and impartial tribunal established by law, if they face any criminal charges or if their rights and obligations are determined in a suit at law. In such proceedings the media and the public may be excluded from the hearing only in the cases specified in the third sentence of paragraph 1. Paragraphs $2-5$ of the article contain procedural guarantees available to persons charged with a criminal offence. Paragraph 6 secures a substantive right to compensation in cases of miscarriage of justice in criminal cases. Paragraph 7 prohibits double jeopardy and thus guarantees a substantive freedom, namely the right to remain free from being tried or punished again for an offence for which an individual has already been finally convicted or acquitted. Compared with article 14 , article 15 is very simple, only referring to the right not to be held guilty for an act or omission not constituting a criminal offence.

Fair trial rights are usually classified into three parts: basic rules, minimum guarantees and other provisions. Basic rules of fair trial rights consist of paragraph 1 and paragraph 2 of article 14. Minimum guarantees refer to paragraph 3 of article 14. Other provisions comprise of the rest of article 14 and article 15.

\section{Basic rules of fair trial rights}

Paragraph 1 and paragraph 2 of article 14 provides the right to be equal before the courts; the right to a fair and public hearing by a competent, independent and impartial tribunal established by law; and the right to be presumed innocent.

\subsection{The right to be equal before the courts}

The first sentence of article 14, paragraph 1 guarantees the right to equality before courts and tribunals. The right to be equal before the courts includes all people having equal rights to access to the court and equal equipment between defendants and prosecutors.

Article 14 encompasses the right of access to the courts in cases of determination of criminal charges and rights and obligations in a suit at law. Access to administration of justice must effectively be guaranteed in all such cases to ensure that no individual is deprived, in procedural terms, of his/her right to claim justice. The right of access to courts and tribunals and equality before them is not limited to citizens of States parties, but must also be available to all individuals, regardless of nationality or statelessness. This guarantee prohibits any distinctions regarding access to courts and tribunals that are not based on law and cannot be justified on objective and reasonable grounds. The guarantee is violated if certain persons are barred from bringing suit against any other persons such as by reason of their race, colour, gender, language, religion, political or other opinion, national or social origin, property, birth or other status.

The right to equality before courts and tribunals also ensures equality of arms. This means that the same procedural rights are to be provided to all the parties unless distinctions are based on law and can be justified on objective and 
reasonable grounds. There is no equality of arms if, for instance, only the prosecutor, but not the defendant, is allowed to appeal a certain decision.

\subsection{The right to a fair and public hearing by a competent, independent and impartial tribunal established by law}

The requirement of competence, independence and impartiality of a tribunal in the sense of article 14, paragraph 1, is an absolute right that is not subject to any exception.

The requirement of independence refers, in particular, to the procedure and qualifications for the appointment of judges, and guarantees relating to their security of tenure until a mandatory retirement age or the expiry of their term of office, where such exist, the conditions governing promotion, transfer, suspension and cessation of their functions, and the actual independence of the judiciary from political interference by the executive branch and legislature. States should take specific measures guaranteeing the independence of the judiciary, protecting judges from any form of political influence in their decision-making through the constitution or adoption of laws establishing clear procedures and objective criteria for the appointment, remuneration, tenure, promotion, suspension and dismissal of the members of the judiciary and disciplinary sanctions taken against them. In order to safeguard their independence, the status of judges, including their term of office, their independence, security, adequate remuneration, conditions of service, pensions and the age of retirement shall be adequately secured by law.

The requirement of impartiality has two aspects. First, judges must not allow their judgement to be influenced by personal bias or prejudice, nor harbour preconceptions about the particular case before them, nor act in ways that improperly promote the interests of one of the parties to the detriment of the other. Second, the tribunal must also appear to a reasonable observer to be impartial. For instance, a trial substantially affected by the participation of a judge who, under domestic statutes, should have been disqualified cannot normally be considered to be impartial. The former is called the subjective test of impartiality, and the latter is called the objective test of impartiality.

All trials in criminal matters must in principle be conducted orally and publicly. The right to a public hearing includes the publicity of hearings and judgment. The publicity of hearings ensures the transparency of proceedings and thus provides an important safeguard for the interest of the individual and of society at large. Courts must make information regarding the time and venue of the oral hearings available to the public and provide for adequate facilities for the attendance of interested members of the public, within reasonable limits, taking into account, inter alia, the potential interest in the case and the duration of the oral hearing. Article 14, paragraph 1, acknowledges that courts have the power to exclude all or part of the public for reasons of morals, public order or national security in a democratic society, or when the interest of the private lives of the parties so requires, or to the extent strictly necessary in the opinion of the court in special circumstances where publicity would be prejudicial to the interests of justice. Even in cases in which the public is excluded from the trial, the judgment, including the essential findings, evidence and legal reasoning must be made public, except where the interest of juvenile persons otherwise requires, or the proceedings concern matrimonial disputes or the guardianship of children. The publicity of judgment has two means: oral publicity and documentary publicity.

\subsection{The right to be presumed innocent}

According to article 14, paragraph 2 everyone charged with a criminal offence shall have the right to be presumed innocent until proven guilty according to law. The presumption of innocence, which is fundamental to the protection of human rights, imposes on the prosecution the burden of proving the charge, guarantees that no guilt can be presumed until the charge has been proved beyond reasonable doubt, ensures that the accused has the benefit of doubt, and requires that persons accused of a criminal act must be treated in accordance with this principle. Defendants should normally not be shackled or kept in cages during trials or otherwise presented to the court in a manner indicating that they may be dangerous criminals. The media should avoid news coverage undermining the presumption of innocence.

\section{The minimum guarantees of fair trial rights}

\subsection{The right to be informed of the charge}

The right of all persons charged with a criminal offence to be informed promptly and in detail in a language which they understand of the nature and cause of criminal charges brought against them, enshrined in paragraph 3 (a), is the first of the minimum guarantees in criminal proceedings of article 14. Notice of the reasons for an arrest is separately guaranteed in article 9, paragraph 2 of the Covenant. Paragraph 3 (a) is only applicable to formal prosecution. The right to be informed of the charge "promptly" requires that information be given as soon as the person concerned is formally charged with a criminal offence under domestic law, or the individual is publicly named as such. The right to be informed of the charge "in detail" requires that the information indicates both the law and the alleged general facts on which the charge is based.

\subsection{The right to prepare defence and to communicate with counsel}

Subparagraph 3 (b) provides that accused persons must have adequate time and facilities for the preparation of their 
defence and to communicate with counsel of their own choosing. This provision is an important element of the guarantee of a fair trial and an application of the principle of equality of arms.

What counts as "adequate time" depends on the circumstances of each case. If counsel reasonably feels that the time for the preparation of the defence is insufficient, it is incumbent on them to request the adjournment of the trial. A State party is not to be held responsible for the conduct of a defence lawyer, unless it was, or should have been, manifest to the judge that the lawyer's behaviour was incompatible with the interests of justice. "Adequate facilities" must include access to documents and other evidence; this access must include all materials that the prosecution plans to offer in court against the accused or that are exculpatory.

\subsection{The right to be tried without undue delay}

The right of the accused to be tried without undue delay, provided for by article 14, paragraph 3 (c), is not only designed to avoid keeping persons too long in a state of uncertainty about their fate and, if held in detention during the period of the trial, to ensure that such deprivation of liberty does not last longer than necessary in the circumstances of the specific case, but also to serve the interests of justice. This guarantee relates not only to the time between the formal charging of the accused and the time by which a trial should commence, but also the time until the final judgement on appeal. All stages, whether in first instance or on appeal must take place "without undue delay". What is reasonable has to be assessed in the circumstances of each case, taking into account mainly the complexity of the case, the conduct of the accused, and the manner in which the matter was dealt with by the administrative and judicial authorities. In cases where the accused are denied bail by the court, they must be tried as expeditiously as possible.

\subsection{The right to be present during trial, to defend and to legal assistance}

Article 14, paragraph 3 (d) contains three distinct guarantees. First, the provision requires that accused persons are entitled to be present during their trial. Proceedings in the absence of the accused may in some circumstances be permissible in the interest of the proper administration of justice, i.e. when accused persons decline to exercise their right to be present, although the necessary steps are taken to summon accused persons in a timely manner and to inform them beforehand about the date and place of their trial and to request their attendance.

Second, the right to defend refers to two types of defence which are not mutually exclusive. Persons assisted by a lawyer have the right to instruct their lawyer on the conduct of their case, within the limits of professional responsibility, and to testify on their own behalf. At the same time, paragraph 3 (d) provides for a defence to be conducted in person "or" with legal assistance of one's own choosing, thus providing the possibility for the accused to reject being assisted by any counsel. However, this right to defend oneself without a lawyer is not absolute. The interests of justice may require the assignment of a lawyer against the wishes of the accused, particularly in cases of persons substantially and persistently obstructing the proper conduct of trial, or facing a grave charge but being unable to act in their own interests, or where this is necessary to protect vulnerable witnesses from further distress or intimidation if they were to be questioned by the accused.

Third, paragraph 3 (d) guarantees the right to have legal assistance assigned to accused persons whenever the interests of justice so require, and without payment by them in any such case if they do not have sufficient means to pay for it. The gravity of the offence is important in deciding whether counsel should be assigned "in the interest of justice". In cases involving capital punishment, it is axiomatic that the accused must be effectively assisted by awyer at all stages of the proceedings. Counsel provided by the competent authorities on the basis of this provision must be effective in the representation of the accused. Unlike in the case of privately retained lawyers, blatant misbehaviour or incompetence may entail the responsibility of the State concerned for a violation of article 14, paragraph 3 (d), provided that it was manifest to the judge that the lawyer's behaviour was incompatible with the interests of justice.

\subsection{The right to call and examine witnesses}

Paragraph 3 (e) of article 14 guarantees the right of accused persons to examine, or have examined, the witnesses against them and to obtain the attendance and examination of witnesses on their behalf under the same conditions as witnesses against them. As an application of the principle of equality of arms, this guarantee is important for ensuring an effective defence by the accused and their counsel. There are two ways to question and challenge witnesses: personally and through their counsel. Giving the defendants a proper opportunity to question and challenge witnesses against them during the trial or other stages of the proceedings can fulfill the requirement of paragraph 3 (e). It does not, however, provide an unlimited right to obtain the attendance of any witness requested by the accused or their counsel, but only a right to have witnesses admitted that are relevant for the defence.

\subsection{The right to the free assistance of an interpreter}

The right to have the free assistance of an interpreter if the accused cannot understand or speak the language used in court as provided for by article 14, paragraph 3 (f) enshrines another aspect of the principles of fairness and equality of arms in criminal proceedings. This right arises at all stages of the oral proceedings. It applies to aliens as well as to 
nationals. However, accused persons whose mother tongue differs from the official court language are, in principle, not entitled to the free assistance of an interpreter if they know the official language sufficiently to defend themselves effectively.

\subsection{The privilege against self-incrimination}

Article 14, paragraph $3(\mathrm{~g})$, guarantees the right not to be compelled to testify against oneself or to confess guilt. This safeguard must be understood in terms of the absence of any direct or indirect physical or undue psychological pressure from the investigating authorities on the accused, with a view to obtaining a confession of guilt. Domestic law must ensure that statements or confessions obtained in violation of article 7 of the Covenant are excluded from the evidence, except if such material is used as evidence that torture or other treatment prohibited by this provision occurred, and that in such cases the burden is on the State to prove that statements made by the accused have been given of their own free will. The privilege against self-incrimination doesn't allow drawing adverse inferences from the defendant's silence.

\section{Other provisions of fair trial rights}

\subsection{The special guarantees for juvenile persons}

Article 14, paragraph 4, provides that in the case of juvenile persons, procedures should take account of their age and the desirability of promoting their rehabilitation. Juveniles are to enjoy at least the same guarantees and protection as are accorded to adults under article 14. In addition, juveniles need special protection. In criminal proceedings they should, in particular, be provided with appropriate assistance in the preparation and presentation of their defence; be tried as soon as possible in a fair hearing in the presence of legal counsel, other appropriate assistance and their parents or legal guardians, unless it is considered not to be in the best interest of the child. Detention before and during the trial should be avoided to the extent possible. Whenever appropriate, measures other than criminal proceedings, such as mediation between the perpetrator and the victim, conferences with the family of the perpetrator, should be considered, provided they are compatible with the requirements of ICCPR and other relevant human rights documents.

\subsection{The right to appeal}

Article 14, paragraph 5 provides that anyone convicted of a crime shall have the right to have their conviction and sentence reviewed by a higher tribunal according to law. The right to appeal is also known as the right to be reviewed. The Human Rights Committee considers that the right to appeal is absolute. The absolute nature of the right to appeal is reflected in the following three aspects: the right of appeal applies to all types of crimes, that is, not only applies to serious crimes; the right to appeal applies not only to the case of conviction in the first instance, but also equally applies to the case whose acquittal judgment in the first instance is overturned in second instance; the Supreme Court can not enjoy the jurisdiction of first instance. In order to effectively protect the right to appeal, the appeal court cannot limit the scope of trial to the legal issues. However, the right to appeal does not call for a comprehensive review, as long as the appeal court reviewing the facts of the case would be sufficient. In addition, the leave to appeal does not necessarily violate the right to appeal.

\subsection{The right to compensation for wrongful conviction}

According to paragraph 6 of article 14, compensation according to the law shall be paid to persons who have been convicted of a criminal offence by a final decision and have suffered punishment as a consequence of such conviction, if their conviction has been reversed or they have been pardoned on the ground that a new or newly discovered fact shows conclusively that there has been a miscarriage of justice. The right to compensation for wrongful conviction is based on the following four conditions: Firstly, a person has by a final decision been convicted of a criminal offence. Secondly, subsequently his conviction has been reversed or he has been pardoned on the ground that a new or newly discovered fact shows conclusively that there has been a miscarriage of justice. Thirdly, the person who was convicted is not responsible for the non-disclosure of the unknown fact in time. Fourthly, penalties have been actually implemented.

\subsection{The right against second trial for the same offence}

Article 14, paragraph 7, providing that no one shall be liable to be tried or punished again for an offence of which they have already been finally convicted or acquitted in accordance with the law and penal procedure of each country, embodies the principle of ne bis in idem. This provision prohibits bringing a person, once convicted or acquitted of a certain offence, either before the same court again or before another tribunal again for the same offence. The principle of ne bis in idem is not at issue if a higher court quashes a conviction and orders a retrial. Furthermore, it does not prohibit the resumption of a criminal trial justified by exceptional circumstances, such as the discovery of evidence which was not available or known at the time of the acquittal. It also does not prohibit the resumption of a criminal trial with respect to the national jurisdictions of two or more States, although States should made efforts to prevent retrial for the same criminal offence through international conventions. 


\subsection{The right not to be held guilty for an act or omission not constituting a criminal offence}

Article 15 requires that no one shall be held guilty of any criminal offence on account of any act or omission which did not constitute a criminal offence, under national or international law, at the time when it was committed. Article 15 also requires that no one shall be imposed a heavier penalty than the one that was applicable at the time when the criminal offence was committed. If, subsequent to the commission of the offence, provision is made by law for the imposition of the lighter penalty, the offender shall benefit thereby. However, nothing in this article shall prejudice the trial and punishment of any person for any act or omission which, at the time when it was committed, was criminal according to the general principles of law recognized by the community of nations.

\section{Conclusion}

In addition to the 16 concrete guarantees mentioned above, article 14, paragraph 1 provides a special kind of right- - the general right to a fair trial. (“...everyone shall be entitled to a fair ...hearing...")Unlike the concrete guarantees, the general right to a fair trial requires to evaluate the proceedings as a whole. If any of these concrete guarantees are not respected, the trial cannot be viewed as having been fair. However, on the other hand, the fact that those rights have been respected does not yet guarantee that the trial was fair. Fairness of proceedings entails the absence of any direct or indirect influence, pressure or intimidation or intrusion from whatever side and for whatever motive. A hearing is not fair if, for instance, the defendant in criminal proceedings is faced with the expression of a hostile attitude from the public or support for one party in the courtroom that is tolerated by the court, thereby impinging on the right to defence, or is exposed to other manifestations of hostility with similar effects. Expressions of racist attitudes by a jury that are tolerated by the tribunal, or a racially biased jury selection are other instances which adversely affect the fairness of the procedure. The general right to a fair trial makes the right to a fair trial be exoteric, and can accommodate to the development of the society. In the process of interpreting ICCPR, the Human Rights Committee has added more and more concrete guarantees to fair trial rights via the general right to a fair trial.

\section{References}

Communication No. 1086. (2002). Weiss v. Austria, para. 9.6.

Communication No. 1128. (2002). Márques de Morais v. Angola, para. 5.4.

Communication No. 1128. (2002). Morais v. Angola, para. 5.6.

Communication No. 277. 91988). Terán Jijón v. Ecuador, para. 5.4.

Communication No. 383. (1989). H.C. v. Jamaica, para. 6.3.

Communication No. 646. (1995). Lindon v. Australia, para. 6.5.

Communication No. 818. (1998). Sextus v. Trinidad and Tobago, para. 7.2.

Communications No. 1033. (2001). Singarasa v. Sri Lanka, para. 7.4.

Communications No. 1089. (2002). Rouse v. Philippines, para.7.4.

Communications No. 16. (1977). Mbenge v. Zaire, para. 14.1.

Communications No. 692. (1996). A.R.J. v. Australia, para. 6.4; No. 204/1986, A.P. v. Italy, para. 7.3.

Communications No. 705. (1996). Taylor v. Jamaica, para. 6.2.

Communications No. 985. (2001). Aliboeva v. Tajikistan, para. 6.4.

Concluding observations, Slovakia, CCPR/C/79/Add.79. (1997), para. 18.

Changyong Sun. (2008). "Controlling Death Penalty via due Process of Law — on the Perfection of Death Penalty Proceedings in China from the Perspective of Fair Trial Rights", Law Review of Nanjing University, 1.

Jixi Zhang. (2009). “On the Principle of ne bis in idem in ICCPR”, Journal of Southwest University of Nationalities, 5. 